\author{
Guba Larysa. \\ Candidate of Philology, \\ Senior Professor of the Department \\ of Foreign Philology \\ Kyiv National University of Culture and Arts \\ ORCID 0000-0003-2295-8458 \\ gubalarisa@ukr.net \\ Rybinska Yulia \\ Doctor of Pedagogical Sciences, Professor, \\ Head of the Department of Foreign Philology \\ of Kyiv National University of Culture and Arts \\ ORCID 0000-0002-2982-8245 \\ Researcher ID: M-3781-2018 \\ Julialeo1619@gmail.ru \\ Ponochovna-Rysak Taisiia \\ Candidate of Pedagogical Sciences, \\ Associate Professor of the Department \\ of Foreign Philology \\ Kyiv National University of Culture and Arts \\ ORCID 0000-0002-2107-3343 \\ ponochovna@bigmir.net
}

\title{
BRITISH HERITAGE AND ITS INFLUENCE ON THE MALTESE CULTURE
}

Purpose of the article. The article highlights the ties between the United Kingdom and Malta and it is shown that they are indissoluble. They run deep, go back centuries, and are founded on mutual respect in good times and bad. The author, Jesmond Grech, rightly dwells on the period from 1800, when the Royal Navy and the people of Malta struck up a friendship which was built to last throughout and beyond the period of British rule, and which embraced the Army and the RAF, through the dark years of World War II and to the present day. Today, Malta's self-evident European vocation and Britain's continuing friendship go band in the band. Among the visible signs are the English language, education choices, tourism, culture - including football - trade and investment. Not to mention Leyland buses, red pillar boxes, and phone kiosks, and abiding affection for things British. With the acquisition of Malta, the British had gained an indispensable Mediterranean naval base. The Grand Harbour area, especially the dockyard was given the utmost consideration. As technological developments constantly the Admiralty invested in the modernization of the harbour facilities. With the opening of the Suez Canal (1869) the naval traffic which passed through Malta on its way to or from India multiplied considerably. Consequently two docks, the Somerset Dock (1871) and the Hamilton Dock (1892) were constructed to meet the demands of heavier shipping. At Vittoriosa one can still see the hub of the Victualling Yard, the Naval Bakery. In this place the Navy's daily bread supplies were prepared by the use of steam-powered machinery. The building was constructed according to the design of William Scamp, a British architect and military engineer, between 1842 and 1845. Previously, the site served as the covered slipways from which the Order's ships were launched. Presently the building is the premises of the Maritime Museum and houses an interesting collection of naval memorabilia from Punic to modern times. In 1903 the construction of the breakwaters at the entrance of the Grand Harbour was commenced. The foundation stone of this project was laid by King Edward VII himself on April 20th 1903. Work on this massive construction project was to provide the livelihood to hundreds of workers and their families for the next three years. Consequently, the initial years of the $20^{\text {th }}$ century augured well. Things, however, began to turn sour both in the local and international scene. Conclusions. The aim of the article is to highlight Malta`s benefit from increased defense spending by Britain. Although Malta remained heavily dependent on British military spending, successive British governors brought advances in medicine, education, industry and agriculture to Malta. The British legacy in Malta is evident in the widespread use of the English language in Malta today. English was adopted as one of Malta's two official languages in 1936, and it has now firmly replaced Italian as the primary language of tertiary education, business, and commerce in Malta.

Key words: ties between the United Kingdom and Malta, British Heritage, the Maltese Culture, English language, integration of cultures, the influence of British, a British colony, British governorship, the blend of Mediterranean Britishness.

Губа Лариса Василівна, кандидат фрілологічних наук, доцент з наказу кафредри іноземної фрілології КНУКіМ; Рибінська Юлія Анатоліївна, доктор педагогічних наук, професор, завідувач кафедри іноземної фрілології КНУКіМ; ПоночовнаРисак Таісія, кандидат педагогічних наук, доцент кафедри іноземної фрілології КНУкіМ

Спадщина Великобританії та їі вплив на культуру Мальти

Мета статті визначена у тому, щоб підкреслити переваги та позитивний подальший вплив Великобританії на життя та культуру Мальти. Вплив Британії на життя Мальти є очевидним у поширенні Англійської мови сьогодні. Англійська мова з 1936р. стала офіційною в країні, витіснивши Італійську, яка на початку була мовою освіти, бізнесу та комерції на Мальті. У статті висвітлюються зв'язки між Великобританією та Мальтою. Вони встановлювалися в далекому минулому та засновані на взаємоповазі та добрі. Автор, Джесмонд Греч, влучно зазначає на періоді з 1800 pp., у часи, коли Royal Navy та жителі Мальти вибудовували дружбу, яка була побудована у часи британського правління. Сьогоднішні відносини та взаємозв'язки Мальти є очевидними. Одним з таких значимих факторів є Англійська мова, вибір освіти, туризм, культура - включаючи футбол, торгівлю та інвестиції. У статті також зазначено вплив Великобританії: Ley-land автобуси, червоні телефонні будки та ін. 3 окупацією Мальти, британці отримали Середземоморську базу. Під час технологічного розвитку багато інвестицій було спрямовано на модернізацію порту.

Ключові слова: зв'язки між Великобританією та Мальтою, британський спадок, культура Мальти, англійська мова, інтеграція культур, вплив британців, британська колонія, суміш британців з середземноморцями.

(C) Guba L., 2019

(C) Rybinska Yu., 2019

(C) Ponochovna-Rysak T., 2019 
Губа Лариса Васильевна, кандидат филологических наук, доцент по приказу кафредры иностранной филологии КНУКиИ; Рыбинская Юлия Анатольевна, доктор педагогических наук, профессор, заведующая кафедрой иностранной филологии КНУКИИ; Поночовная-Рысак Таисия, кандидат педагогических наук, дочент кафедры иностранной филологии КНУКИИ.

Наследство Великобритании и её влияние на культуру Мальты

Цель статьи определена в том, чтобы подчеркнуть преимущества и положительный дальнейшее влияние Великобритании на жизнь и культуру Мальты. Влияние Британии на жизнь Мальты очевидно в распространении Английского языка сегодня. Английский язык с 1936г. стала официальным в стране, вытеснив Итальянский, который в начале был языком образования, бизнеса и коммерции на Мальте.В статье освещаются связи между Великобританией и Мальтой. Они устанавливались в далеком прошлом и основанные на взаимоуважении и доброте. Автор, Джесмонд Греч, отмечает период с 1800 гг. во времена, когда Royal Navy и жители Мальты выстраивали дружбу, которая была построена во времена Британского правления. Сегодняшние отношения и взаимосвязи Мальты очевидны. Одним из таких значимых факторов является Английский язык, выбор образования, туризм, культура - включая футбол, торговлю и инвестиции. В статье также отмечается влияние Великобритании: Ley-land автобусы, красные телефронные будки и др. С оккупацией Мальты, Британцы получили Средиземную морскую базу. Во время технологического развития много инвестиций было направлено на модернизацию порта.

Ключевые слова: связи между Великобританией и Мальтой, Британское наследие, культура Мальты, Английский язык, интеграция культур, влияние британцев, британская колония, смесь британцев с средиземноморцами.

The influence of the British on the Maltese way of life is evident in many aspects. The British systems of administration, education, and legislation were adopted and adapted by the islanders. During the years of British governorship, the foundation stones were laid so that Malta could become a modern state. The aim of the article is to list but a few places of interest which immediately bring back to mind the British presence on the islands. The constitutional history of Malta during the $19^{\text {th }}$ century is a series of so-called Councils of Government in which members elected by the Maltese vied for power with others chosen officially by the British Government. It was, in reality, a question of which side was to have a majority in the Council. The 1849 Constitution was the first one in which the elected element was introduced even though kept in a minority. The member elected to represent Gozo on the Council of Government was a young lawyer with a brilliant future. Dr. (later Sir) Adrian Dingli began a distinguished career during which he was appointed Crown Advocate, Knight Commander of the Order of St. Michael and St. George as well as serving on many important diplomatic missions abroad. In 1878 two Royal Commissioners, Sir Penrose Julyan and Patrick J. Keenan, visited Malta and produced their controversial reports by which the use of English above Italian was promoted in the cultural, educational and judicial spheres. Up to that year, the local intelligentsia was deeply soaked in Italian cultures and spirit. Italian was the language of the educated classes and it served as the language of the courts as well as the medium of instruction. An attack on Italian was considered as an attack on their social position. It is not surprising that the Commissioners' reports proved to be a watershed for Maltese politicians. These were roughly divided into two factions; those who supported the reforms and consequently were sympathetic to British rule in general and those who were against. This issue (which later became known as "The Language Question») was the foundation stone of party politics in Malta. The Reform Party and the Partito Anti-Reformista came into existence. The former was in favor of the proposed reforms and included among its supporters the people whose livelihood depended upon or was greatly enhanced by the presence of the British such as dockyard workers, merchants and those who looked upon Britain as a role model for future Malta. The later included men of letters, the local energy, the middle class in general especially lawyers who were the traditional leaders of the Maltese. The opposition was soon to utilize its majority in the Council (a majority catered for by the 1887 constitution) to block the influence of the English language primarily in schools. The Language Question was not just a battle between English and Italian; it was only the tip of the iceberg. The main issue was whether the British were to have complete control over education and Malta's historic links with Italy were to be broken forever. The majority of the elected members were pro-Italians and they were going to do their best not to let what Britain dictated happen even to the detriment of progress in education. As a result of this situation, an impasse was created when the Government's estimates to finance schools were not passed by the Council. In 1903, the 1887 Constitution was reworked and replaced by one whereby the elected members were in a minority. The predominant religion in Malta is Catholicism, which is followed by over $90 \%$ of the population and therefore has a reasonable amount of authority compared to other European states. Mass attendance is also relatively high in this regard, with $52.6 \%$ of the population attending Sunday mass, according to 2005 data. Seemingly following a European trend, however, the younger generations seem to be becoming less interested in practicing religion. Malta is seen by many as being a nation of opposites and opposition. Whereas the Maltese people are generally friendly and welcoming, Mediterranean temperament comes forward in opposition of sides at many levels, but mainly in sports, politics and local band clubs. Opposition and choosing sides give a sense of belonging and identity and this is something that is evident in Maltese culture, in which opposition sometimes flows into conflict. Followers of either side of the contrasting entities often lose touch with reality and conflict has at times escalated and become physical. This is not something that occurs regularly but temperament (and not aggression) is part and parcel of life in Malta, where something as subtle as whispering is a rare occurrence and where oral communication is often much louder than in Northern Europe. Maltese culture, language, and politics underwent radical changes under British rule, from 1800 to 1964. The addition of Malta to the British Empire was a voluntary request made by the Maltese people in an attempt to rid the Maltese islands of the French. Its strategic location in the center of the Mediterranean made Malta an excellent station for British 
forces, whilst the opening of the Suez Canal further improved the importance of Malta as a supply station and naval base. British rule, from 1800 to 1964, radically and permanently transformed the language, culture, and politics of Malta. Malta's position in the British Empire was unique in that it did not come about by conquest or by colonization, but at the voluntary request of the Maltese people. Britain found in Malta an ancient, Christian culture, strongly influenced by neighboring Italy and Sicily, and loyal to the Roman Catholic Church. Malta's primary utility to Great Britain lay in its excellent natural harbors and strategic location, and for many decades, Malta was essentially a "fortress colony". The British period introduced the Neoclassical style of architecture to Malta, evident in several palaces built during this period, in the Greek revival portico of the parish church of Sta. Marija Assunta in Mosta, and in the soaring spire of St Paul's Anglican Cathedral which, alongside the massive Baroque dome of a nearby Catholic church, dominates the Valletta skyline. The neo-gothic architecture was also introduced to Malta during this period, such as in the Chapel of Santa Maria Addolorata at Malta's main cemetery, and in the Carmelite Church in Sliema. Sliema itself, which developed from a sleepy fishing village into a bustling, cosmopolitan town during the British period, once boasted an elegant seafront that was famed for its Regency style architecture that was strongly reminiscent of the British seaside town of Brighton. Of all the periods in Maltese history, the time when Malta was a British colony is the one that still generates emotional debate. The main reason for this is that many Maltese still remember British rule with a certain degree of nostalgia. Likewise, British nationals presently residing in Malta always point out that the British were invited to Malta. Although the British brought improvements to the Maltese economy, education and medical sectors, the Maltese longed for self-rule. They never forgot that they had asked the British to come to Malta to expel the French. During the Great War (World War I), Malta came to be known as the nurse of the Mediterranean as it served as a hospital for the injured. Meanwhile, its strategic position led to its own drawback during WW II when the island suffered heavy bombing and many casualties. It was during this period, in 1942, that the George Cross was awarded and it to this day forms part of the Maltese flag: "To honour her brave people I award the George Cross to the island fortress of Malta to bear witness to a heroism and devotion that will long be famous in history"[3,5]. After World War II the islands achieved self-rule once again and then the question of whether Malta should be integrated with Britain or achieve independence was one that would occupy the Maltese for over a decade. Independence was granted in 1964 but Malta was still considered a Monarchy under Queen Elizabeth II. By 1974 Malta became a Republic with the head of state being a Maltese President. The decreasing strategic importance of Malta to the Royal Navy meant that the British government was increasingly reluctant to maintain the naval dockyards and by 1979 Malta stopped being used as a British military base. To this day the presence of the British influence in Malta is felt throughout the islands, from the use of English as one of Malta's official languages to the many buildings and monuments. The British introduced the Neoclassical style of architecture to Malta, evident in several palaces built during this period, in the Greek revival portico of the parish church of Sta. Marija Assunta in Mosta, and in the soaring spire of St Paul's Anglican Cathedral which dominates the Valletta skyline. The neo-gothic architecture was also introduced to Malta during this period, in the Chapel of Santa Maria Addolorata at Malta's main cemetery, and in the Carmelite Church in Sliema. Sliema itself, which developed from a sleepy fishing village into a bustling, cosmopolitan town during the British period, once boasted an elegant seafront that was famed for its Regency style architecture, strongly reminiscent of the British seaside town of Brighton. British traditions that live on in Malta include an efficient civil service, a military that is based on the British model, a Westminster-style parliamentary structure, a governmental structure premised on the rule of law, and a legal system based on common law. Another British legacy in Malta is the widely popular annual Christmas pantomime at the Manoel Theatre. Most Maltese families have adopted turkey and plum pudding as Christmas treats in place of the more traditional Maltese rooster and cassata. Due to Malta forming a part of the British Empire in the 19th and 20th centuries, and a considerable amount of intermarriage has taken place during that time period, the existence of British or Irish surnames is increasingly common. Examples include Alden, Atkins, Crockford, Ferry, Gingell, Hall, Hamilton, Harmsworth, Harwood, Jones, Mattocks, Moore, O'Neill, Sladden, Sixsmith, Smith, Strickland, St. John, Turner, Wallbank, Warrington, Kingswell and Woods.

While British rule ended in 1964, its traces and influences in Maltese culture are still visible. Maltese versions of English words are often used in a more formal language, while the more wealthy families often use English as the primary language used in the household and in some instances children are brought up without being taught, Maltese. In material form, many remnants of British rule remain, with the most simple examples being mail collection boxes and phone boxes having been left in their original placements. The Islands became part of the British Commonwealth. Malta was part of the British Empire for over 150 years, so it is hardly surprising that business, laws and education have some British overtones. Today, you'll find plenty of this special blend of Mediterranean Britishness and The British Period is a very significant era in Maltese history. World Wars and Maltese Independence are the most historic dates of the period. The British legacy still lives on in many aspects of daily life in Malta today. After assisting the Maltese to expel the French, the British found themselves sovereign of the Islands but were at first uncertain as to whether they should retain the territory. The Treaty of Amiens in 1802 established that Malta would be passed back to the Order of St. John, but some locals were not keen to return to their former rulers and requested to remain under British protection. As it happened, the Peace of Amiens was short-lived and the Napoleonic wars re- 
sumed. The British were thus committed to defend Malta and would eventually gain full sovereignty of the Maltese Islands by the provisions of the Treaty of Paris in 1814. From then on, Malta became an important part of the British Empire, a strategic stronghold in the region and a stepping stone for Britain's expansion to the East. Through cycles of war and peace, Malta's fortunes were inextricably linked to those of Britain. This was never more evident than during World War II when the islands played a pivotal role in the Mediterranean theatre of war. The role of the Maltese Islands during the First World War as a supply station and as a base for the recovery of the injured earned the Islands the title, 'Nurse of the Mediterranean'. Malta was part of the British Empire for over 150 years, so it is hardly surprising that business, laws, and education have some British overtones. Today, you'll find plenty of this special blend of Mediterranean Britishness around in Maltese daily life. English is a joint official language with Maltese. It is spoken fluently and widely. But English, as other languages such as Italian, has made an impact on the daily conversation in Maltese (Malti). The Maltese often switch effortlessly from Malti to English mid-sentence. Walking through the capital, Valletta, you'll come across shops and cafes with British names harking back to mid last century. Visitors are always surprised and charmed to see old-fashioned, red-painted, British letter and phone boxes when this street furniture has all but disappeared in the UK itself. Driving is on the left, as in the UK. Out and about on the road, you'll come across a number of old British cars: Morris Minors, Ford Anglias and Prefects, Triumphs and Bedford lorries. Many are used regularly for daily travel, but others have lovingly cared for vintage models seen out only on special occasions. Maltese cooking has also adopted some elements of British fare: local bars and cafes serve the British breakfast and brunch. Beer is a favourite drink here as in the UK, and is sold in 'pints' and 'half-pints' rather than liters.

The British never bothered Maltese culture or imposed their religion on them, Joseph says. His opinion is that the British presence in Malta was beneficial, not only for the economy but also because of the introduction of the English language. "That is the way the world progresses," says Joseph. "Everyone is learning something. The English language is something that we have in common, and it can be used for everything, especially talking with the tourists; otherwise they wouldn't come here at all"[12, 3]. A lot of emphases is made on teaching children English from a very young age, even in countries where the first language is the mother tongue since it is an international language. We are from an early age encouraged to read English authors such as Charles Dickens, Roald Dahl, Shakespeare, lan McEwan, and many others, and we are heavily influenced by the English language. The culture of Malta is the culture of the Maltese islanders and reflects various societies that have come into contact with the Maltese Islands throughout the centuries, including neighbouring Mediterranean cultures, and the cultures of the nations that ruled Malta for long periods of time prior to its independence in 1964. The culture of modern Malta has been described as a "rich pattern of traditions, beliefs and practices," which is the result of "a long process of adaptation, assimilation and cross fertilization of beliefs and usages drawn from various conflicting sources." It has been subjected to the same complex, historic processes that gave rise to the linguistic and ethnic admixture that defines who the people of Malta and Gozo are today. Maltese culture has both Semitic and Latin European origins and a British legacy is also evident. The Latin European element is more readily apparent in modern Malta because of virtually continuous cultural impact on Malta over the past eight centuries and the fact that Malta shares the religious beliefs, traditions, and ceremonies of its Sicilian and Southern European neighbors. Catholicism It is said that in Malta, Gozo, and Comino there are more than 360 churches or one church for every 1,000 residents. According to tradition and as recorded in the Acts of the Apostles, the Church in Malta was founded by St. Paul in $70 \mathrm{CE}$, following his shipwreck on these Islands. The earliest Christian place of worship in Malta is said to be the cavern on the north-east of Malta, now known as St. Paul's Grotto, where the apostle was imprisoned during his stay on Malta. There is evidence of Christian burials and rituals having taken place in the general vicinity of the Grotto, dating back to the 3rd century CE. Further evidence of Christian practices and beliefs during the period of Roman persecution can be found in the many catacombs that lie beneath various parts of Malta, including St Paul's Catacombs and St Agatha's Catacombs in Rabat, just outside the walls of Mdina. The latter, in particular, were beautifully frescoed between 1200 and 1480; they were defaced by marauding Turks in the 1550s. There are also a number of cave churches, including the grotto at Mellieha, which is a Shrine of the Nativity of Our Lady where, according to legend, St. Luke painted a picture of the Madonna. It has been a place of pilgrimage since medieval times. The writings of classic Maltese historian, Gian. Francesco Abela recount the conversion to Christianity of the Maltese population at the hand of St. Paul. It is suggested that Abela's writings were used by Knights of Malta to demonstrate that Malta had been ordained by God as a "bulwark of Christian, European civilization against the spread of Mediterranean Islam." The native Christian community that welcomed Roger I of Sicily was further bolstered by immigration to Malta from Italy, in the 12th and 13th centuries. For centuries, leadership over the Church in Malta was generally provided by the Diocese of Palermo, except under Charles of Anjou who caused Maltese bishops to be appointed, as did - on rare occasions - the Spanish and later, the Knights. This continued Malta's connections with Sicily and Italy, and contributed to, from the 15th century to the early 20th century, the dominance of Italian as Malta's primary language of culture and learning. Since 1808 all bishops of Malta have been Maltese. During the Norman and Spanish periods and under the rule of the Knights, Malta became the devoutly Catholic nation it is today. It is worth noting that the Maltese Inquisition (more properly called the Roman Inquisition) had a very long tenure in Malta following its establishment by the Pope in 
1530; the last Inquisitor departed from the Islands in 1798 after the Knights capitulated to the forces of Napoleon Bonaparte. Maltese Culture Page 3 The Normans Under Roger II, King of Sicily, Christianity was restored as Malta's principal faith The later years of Norman rule over Malta brought massive waves of immigration to the Islands from Sicily and from the Italian mainland, including clergy and notaries. Sicilian became the sole written language of Malta, as evidenced by notarial deeds from this period, but this was eventually supplanted by Tuscan Italian, which became the primary literary language and the medium of legal and commercial transactions in Malta. A large number of Sicilian and Italian words were adopted into the local vernacular. Traces of Siculo-Norman architecture can still be found in Malta's ancient capital of Mdina and in Vittoriosa, most notably in the Palaces of the Santa Sofia, Gatto Murina, Inguanez and Falzon families. The Knights of St. John The population of Malta increased considerably during the rule of the Knights, from 25,000 in 1535 to over 40,000 in 1621 , to over 54,463 in 1632 . This was primarily due to immigration from Western Europe, but also due to generally improved health and welfare conditions, and the reduced incidence of raids from North African and Turkish corsairs. By 1798, when the Knights surrendered Malta to the forces of Napoleon Bonaparte, the population of Malta had increased to 114,000. The period of the Knights is often referred to as Malta's Golden Age, as a result of the architectural and artistic embellishment of the Islands by their resident rulers, and as a result of advances in the overall health, education and prosperity of the local population during this period. Music, literature, theatre and the visual arts all flourished in Malta during this period, which also saw the foundation and development of many of the Renaissance and Baroque towns and villages, palaces and gardens of Malta, the most notable of which is the capital city, Valletta. The city of Valletta, one of several built and fortified by the Knights of Malta Contact between the Maltese and the many Sicilian and Italian mariners and traders who called at Valletta's busy Grand Harbour expanded under Knights, while at the same time, a significant number of Western European nobles, clerics and civil servants relocated to Malta during this period. The wealth and influence of Malta's noble families - many of whom trace their ancestry back to the Norman and Spanish monarchs who ruled Malta prior to the Knights - was also greatly enhanced during this period. Maltese Culture Page 4 Maltese education, in particular, took a significant leap forward under the Knights, with the foundation, in 1530, of the Collegium Melitensæ, a precursor to today's University of Malta, through the intercession of Pope Clement VIII. As a result, the University of Malta is one of the oldest extant universities in Europe and the oldest Commonwealth university outside of the United Kingdom. The School of Anatomy and Surgery was established by Grand Master Fra Nicolas Cotoner at the Sacra Infermeria in Valletta, in 1676. The Sacra Infermeria itself was known as one of the finest and most advanced hospitals in Europe.

Conclusions. It is quintessential to talk with inspiration about the land where the architecture resembles the color of the honeycomb, the fragrance of the citrus groves and fields as the soft quilts. Maltese culture is generally considered to be a mix of influences brought to the island of Malta by the various rulers it has seen come and go over many centuries. It is a fact that the Phoenicians, Romans, and Arabs all left their stamp on the customs and traditions of the Maltese. However, age-old traditions have traveled through generations and have allowed the Maltese to retain their roots. A likely reason for the survival of originally Maltese traits is the drive to establish an own identity in the face of foreign rulers, and more certainly the reliance on maritime trade has helped to shape and conserve what we know now as being Maltese culture.

\section{References}

1. Abela, A.E. (1991). Governors of Malta, Progress Press.

2. Joseph Borg. (1990). The Public Gardens and Gloves of Malta and Gozo, Media Centre.

3. Ray Cachia Zammit (ed.). (1997). The Victoria Lines; souvenir guide.

4. Michael Galea, \& Sir Alexander John Ball, (1990). Publishers Enterprises Group.

5. Alfie Gaullaumier, Bliet u Irhula Maltin. (1992). Vols. 1,2,3., Valletta Publishing.

6. Jesmond Grech. (1997). Malta That I-Inglizi, Klabb Kotba Maltin.

7. Kirkpatrick, R.G. (1988). St. Paul's Anglican Pro-Cathedral; Valetta, Malta G.C.

8. Laferla, A.V. (1976). British Malta, Vols. 1,2., A.C. Aquilina.

9. Various articles from Heritage, Margaret Weaver, Holy Trinity Church; Sliema Malta G.C., 1988.

10. Welsh, A.N. (1995). The Msida Bastion Garden of Rest.

11. Joseph, M. (1991). Brincat, Malta 870-1054 Al-Himyari's Account, Said International.

12. Victor Mallia-Milanes (ed.). (1988). The British Colonial Experience 1800-1964, Mireva

13. Frendo, Henry. (1989). Malta's Quest for Independence, Valletta Publishing.

14. Attard, Joseph. (1988). Britain and Malta; the story of an Era, Publishers Enterprises Group.

15. Ganado, Herbert. (1977). Rajt Malta Tinbidel, Vol. 2, Malta. 